\title{
Application of flotation in the decontamination of sediments from the Cerny prikop stream
}

\author{
Peter Fečko, Iva Janakova, Helena Raclavská, Barbara Tora \\ VSB-Technical University of Ostrava, 17. listopadu 15 Str., 70833 Ostrava-Poruba, Czech Republic, \\ e-mail:peter.fecko@vsb.cz
}

\begin{abstract}
The stream Cerny prikop is located in the Ostrava city districts of Marianske Hory, Moravska Ostrava and Privoz. This locality belongs to the most polluted areas in Ostrava as it is unbearably polluted by the Coking Plant of Jan Sverma, company BorsodChem MCHZ (the chemical plant), City Waste Water Treatment Plant and a number of other companies in the given territory, all the way to its mouth to the Odra River. Moreover, the area is also affected by the construction of the D 47 motorway. The sediments of Cerny prikop represent a significant ecological burden within the Ostrava urban area. They are contaminated by a wide range of organic pollutants which have never been exactly identified.
\end{abstract}

Keywords: flotation, decontamination, Cerný prikop stream.

\section{INTRODUCTION}

The environment has been polluted by a variety of hydrocarbons, oil substances in particular, since the beginning of the last century. In the 1980s their quantities reached alarming 6,000,000 tons a year. A small amount of such contaminating hydrocarbons changes in the environment by oxidation or photochemical reactions. The rest is dispersed by vaporization, dissolves in water, remains in sediments, is covered by ice and a part is degraded by microorganisms. However, the hydrocarbons are really removed from the environment by combustion or by the action of microorganisms. Otherwise, they stay in the environment for many years.

The paper deals with an evaluation of flotation application suitability in the sludge decontamination from the Cerny prikop situated in the City of Ostrava.

\section{DESCRIPTION OF THE CERNY PRIKOP LOCALITY}

The Cerny prikop rises in Ostrava, the municipality of Mariánské Hory, approximately $230 \mathrm{~m}$ above the sea level. It runs through the city district of Moravská Ostrava and Privoz and near the confluence of the Odra and Ostravice Rivers, it issues into the Odra. The course is about $5 \mathrm{~km}$ long and $\mathrm{Q}_{355}$ is $0.074 \mathrm{~m}^{3} \mathrm{~s}^{-1}$. The wastewater from the Jan Sverma Coking Plant and Central Waste Water Treatment Plant for Ostrava (UCOV) is discharged into the Cerny prikop. The average value of $\mathrm{BSK}_{5}$ in 2007 was 7.2 $\mathrm{mg} / \mathrm{l}\left(4^{\text {th }}\right.$ quality class) and CHSK $37.5 \mathrm{mg} / 1$ ( $5^{\text {th }}$ quality class). Also the parameter of ammoniated nitrogen of $3.28 \mathrm{mg} / \mathrm{l}$ places this watercourse into the $5^{\text {th }}$ quality class. Out of the monitored parameters only total phosphorus
$(0.25 \mathrm{mg} / \mathrm{l})$ and electrolytic conductivity of $122 \mathrm{mS} / \mathrm{m}$ are placed in the class 3. The water quality in the Cerny prikop is predominantly determined by the quality of the discharged water from the Jan Sverma Coking Plant $\left(0.014 \mathrm{~m}^{3} \mathrm{~s}^{-1}\right)$ and the water from the Central Waste Water Treatment Plant for Ostrava $\left(0.038 \mathrm{~m}^{3} \mathrm{~s}^{-1}\right)$, which participate in the course aquosity with two thirds. According to a water-management decision only the parameters in Table 1 are observed with both sources.

Within the construction of D 47 motorway a partial relocation of the watercourse into a new bed $(2.47 \mathrm{~km})$ had been planned below the wastewater discharge from the Jan Sverma Coking Plant. The relocation of the watercourse also required a removal of the sediments. The sediment reached the thickness of $1.8 \mathrm{~m}$, the average thickness of the sediment in the bed was $1.2 \mathrm{~m}$ and the minimum thickness of the sediment was $0.2 \mathrm{~m}$ (shipyard). The sediment comprised organic pollutants in the concentrations (See Table 2), which prevented its dumping on a disposal site. Also the content of organic carbon in the sediment solids $(30.82 \%)$ was the second key parameter, which limited their dumping on a disposal site (5\% TOC). The content of heavy metals in the water extract meets the requirements of Regulation 294/2005 Coll. The problem sediment pollutants are mainly PAH, PCB and NEL (hydrocarbons $\mathrm{C} 10$ - C40).

These pollutants get into the sediments predominantly from the wastewater from both the above mentioned sources, larger part being on part of the Jan Sverma Coking Plant and probably there is seepage from the industrial premises of the Jan Sverma Coking Plant and the near-by oil lagoons Ostramo, which affect the content of NEL and

Table 1. The observed parameter average values with the discharged waste water for 2007

\begin{tabular}{|c|c|c|c|c|c|c|c|}
\hline \multirow{2}{*}{ Source } & $\mathrm{BSK}_{5}$ & $\mathrm{CHSK}$ & $\mathrm{NL}$ & RAS & $\mathrm{N}-\mathrm{NH}_{4}{ }^{+}$ & $\mathrm{N}_{\text {inorg }}$ & $\mathrm{P}_{\text {total }}$ \\
\hline & \multicolumn{7}{|c|}{$(\mathrm{mg} / \mathrm{l})$} \\
\hline OKD Jan Šverma Coking Plant & 7.1 & 31.6 & 17.2 & 340 & 2.3 & 5.3 & 0.4 \\
\hline účov Ostrava & 11.3 & 33.5 & 13.7 & 503 & 6.7 & 8.1 & 0.6 \\
\hline
\end{tabular}

Table 2. The organic pollutant content in the sediment solids from the Cerny prikop ( $\mathrm{mg} / \mathrm{kg}$ solids)

\begin{tabular}{|c|c|c|c|c|c|c|c|}
\hline Benzene & BTEX & EOX & NEL & Tetrachlorethene & Trichlorethene & PAH(15) & PCB $(6)$ \\
\hline 3.58 & 8.722 & 14.4 & 2880 & 0.76 & 1.06 & 541 & 0.644 \\
\hline
\end{tabular}

Notes: PCB congeners $28,52,101,138,153,180$ 
PCB in the sediment. According to the requirements NV 229/2007 Coll. six analytes of PAH represented in $\mathrm{SPAH}$ (fluorantene, benzo(b)fluorantene, benzo(k)fluorantene, benzo(a)pyrene, benzo(ghi)perlene, indeno(1,2,3cd)pyrene) are observed on the outlet from the UCOV Ostrava; the free of charge limit is $0.5 \mathrm{~g} /$ day. The substance balance for the above mentioned $\mathrm{PAH}$ analytes implies that in the case of the observed analytes the UCOV Ostrava discharges as much as $10.42 \mathrm{~g} /$ day, $1.14 \mathrm{~g} /$ day of anthracene and in $\mathrm{PAH}$ (15 analytes) it is as much as 67 $\mathrm{g} /$ day. PCB on the outlet from the UČOV is under the detection limit. A significantly higher amount of $\mathrm{PAH}$ is contained in the wastewater from Jan Sverma Coking Plant, where the daily amount for the 15 analytes reaches the value of $133 \mathrm{~g} /$ day.

With regard to the fact that the content of the organic pollutants in the solids exceeded the limits for dumping this waste on disposal sites a suitable decontaminating technology had to be selected, which would permit a safe disposal of the waste on the disposal site or a new method of the utilization of the decontaminated sediment (e.g. for land reclamation).

Figure 1 shows the representation of the individual analytes of PAH. It is apparent from the figure that the socalled "light PAH" amount to about $21 \%$ and the socalled "heavy PAH" represent $79 \%$.

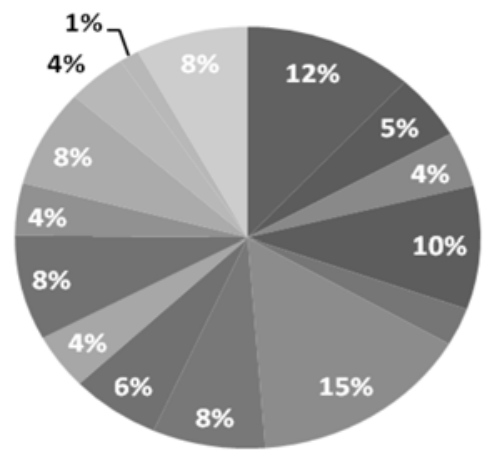

\begin{tabular}{|c|}
\hline Naftalen \\
\hline Acenaften \\
\hline Eluoren \\
\hline Fenantren \\
\hline E Antracen \\
\hline Fluoranten \\
\hline Eyren \\
\hline Benzo(a)antracen \\
\hline Chrysen \\
\hline
\end{tabular}

Figure 1. Individual analytes of $\mathrm{PAH}$

\section{MINERALOGICAL COMPOSITION OF THE CERNY PRIKOP SEDIMENT}

Four samples of sediments from different sampling points were taken. The mineralogical composition analysis of the samples was carried out on an all-levels sample. An X-ray diffraction analysis was done in the laboratories of the Institute of Geological Engineering at VŠB-TU Ostrava. The measurements were carried out on a modernized, fully automated diffractometer URD-6 (Rich. Seifert-FPM, SRN). The following phases were identified on the samples in question: ankerite, chlorite, kaolinite, muscovite, orthoclase, plagioclase, albite, quartz (See Figure 2).

\section{FLOTATION OF CONTAMINATED SEDIMENTS AND SOILS}

Flotation has not been applied in the cleaning of organically contaminated soils and sediments in the Czech Republic so far. In the CR there are only references on the application of flotation, predominantly in the cleaning of oiled water, which can be found in the textbooks on the

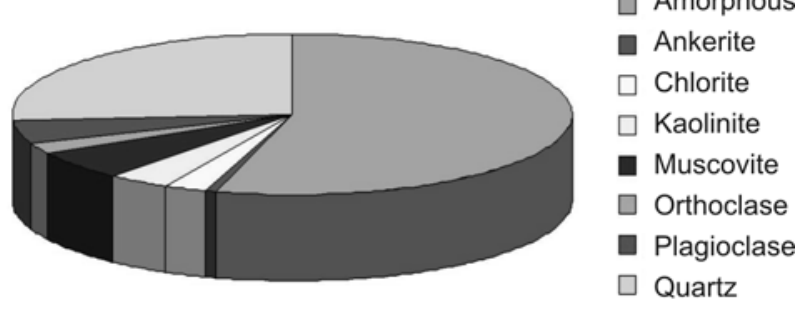

Figure 2. The mineralogical composition of the Cerny prikop sediments

theory of flotation (Kmet, Spaldon). Michael J. Ahrens and Craig V. Depree studied the representation of polycyclic aromatic hydrocarbons in 6-grain sizes of Auckland Harbour sediments in New Zealand. Flotation was used only to distribute $\mathrm{PAH}$ in the individual fractions. A solution of sodium-polytungstate collector was used for the flotation.

In a Dutch scientific study of Mulleneers et al. a new flotation method on laboratory scale was used as an alternative remediation technique. Dissolved air was used to create small bubbles. Tests were performed with the finest fractions of sediments of Overschie (Rotterdam) and Petrol Harbour (Amsterdam) sludges contaminated with Polycyclic Aromatic Hydrocarbons (PAH). Several agents and conditions were tested with respect to the flotation efficiency. For Overschie sludge the best results were obtained without collector and SDS as frother. The PAH concentration in the froth was up to 8 times higher than that in the non-floating fractions. The collected amount of dry matter in the froth was around $13 \%$. With a two-step flotation, the PAH concentration of the non-floating clean fraction was reduced from $240 \mathrm{mg}\left(\mathrm{kg} . \mathrm{d} . \mathrm{m}^{-1}\right)$ to $99 \mathrm{mg}$ (kg.d.m $\left.{ }^{-1}\right)$. For Petrol Harbour sludge the best results were obtained with the alcohol-based frothers Aerofroth and Montanol. The flotation was less selective than with Overschie sediment. Around 50\% solids were collected in the froth and the PAH concentration in the froth was around 2 times higher than in the settled fraction and 35 times higher than in the fraction remains.

\section{FLOTATION EXPERIMENTS}

The flotation experiments were carried out in the laboratories of the Institute of Environmental Engineering at the VSB-TU Ostrava on a flotation machine VRF-1, a product of RD Pribram with an active capacity of 1 litre, under the following conditions:

Condensation: $150 \mathrm{~g} \mathrm{1-1}$

Flotakol NX collector dose: 500 g. $\mathrm{t}^{-1}$

Pulp collector agitation: $1 \mathrm{~min}$

Flotation time: $10 \mathrm{~min}$

Having finished the flotation, the flotation products (both the concentrate and the tailings) were filtered, dried and underwent chemical analyses for PAH, PCB and NEL, which were carried out in the laboratories of VÚHU, a.s. in Most. The flotation experiments were done on 4 samples from different sampling points.

\section{SAMPLE 1}

Sample 1 was taken from a levee situated 200 meters from the chemical plant of Borsodchem, a.s. Ostrava 
Table 3. Flotation results - Sample „Levee"

\begin{tabular}{|c|c|c|c|c|c|c|c|}
\hline \multirow{3}{*}{ Product } & \multirow{2}{*}{ Recovery } & \multicolumn{3}{|c|}{ Content } & \multicolumn{3}{|c|}{ Recovery } \\
\hline & & PAH & $\Sigma \mathrm{PCB}$ & NEL & PAH & $\Sigma$ PCB & NEL \\
\hline & $\%$ & \multicolumn{3}{|c|}{$\mathrm{mg} / \mathrm{kg}$} & \multicolumn{3}{|c|}{$\%$} \\
\hline $\mathrm{K}$ & 65.44 & 216 & 0.291 & 1900 & 80.19 & 92.89 & 72.71 \\
\hline 0 & 34.56 & 101 & 0.042 & 1350 & 19.81 & 7.11 & 27.29 \\
\hline$P$ & 100 & 176.26 & 0.205 & 1710 & 100 & 100 & 100 \\
\hline
\end{tabular}

$\mathrm{K}$ - concentrate, $\mathrm{O}$ - tailings, $\mathrm{P}$ - feed

Table 4. Flotation results - Sample Sverma

\begin{tabular}{|c|c|c|c|c|c|c|c|}
\hline \multirow{3}{*}{ Product } & \multirow{2}{*}{ Recovery } & \multicolumn{3}{|c|}{ Content } & \multicolumn{3}{|c|}{ Recovery } \\
\hline & & $\mathrm{PAH}$ & $\Sigma$ PCB & NEL & $\mathrm{PAH}$ & $\Sigma$ PCB & NEL \\
\hline & $\%$ & \multicolumn{3}{|c|}{$\mathrm{mg} / \mathrm{kg}$} & \multicolumn{3}{|c|}{$\%$} \\
\hline $\mathrm{K}$ & 68.23 & 840 & 0.375 & 2050 & 83.91 & 75.48 & 78.58 \\
\hline $\mathrm{O}$ & 31.77 & 347 & 0.261 & 1200 & 6.09 & 24.52 & 21.42 \\
\hline$P$ & 100 & 683 & 0.339 & 1780 & 100 & 100 & 100 \\
\hline
\end{tabular}

$\mathrm{K}$ - concentrate, $\mathrm{O}$ - tailings, $\mathrm{P}-$ feed

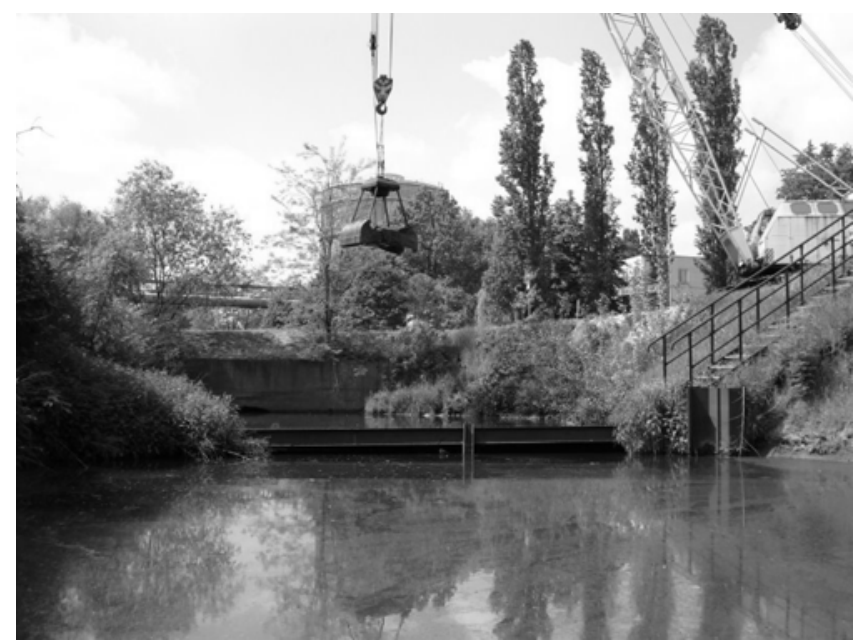

Figure 3. The sampling point of Sample 1 - Levee

(Figure 3). The flotation experiment results are given in Table 3. The obtained results imply that applying flotation it is possible to remove $73 \%$ of NEL, $93 \%$ of PCB and $80 \%$ of PAH from the sediments.

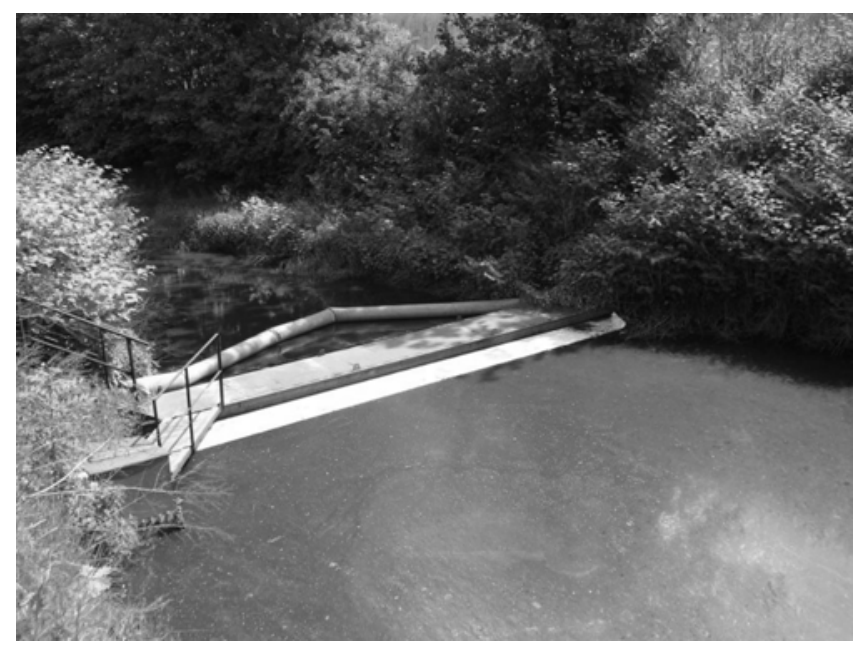

Figure 4. The sampling point of Sample 2 - Sverma

\section{SAMPLE 2}

The second sample was taken from a point placed near the Jan Sverma Coking Plant (Figure 4). Table 4 shows the results of its flotation experiments. It is apparent from the acquired results that when applying flotation it is possible to remove $79 \%$ of NEL, $75 \%$ of PCB and $84 \%$ of PAH from the sediments.

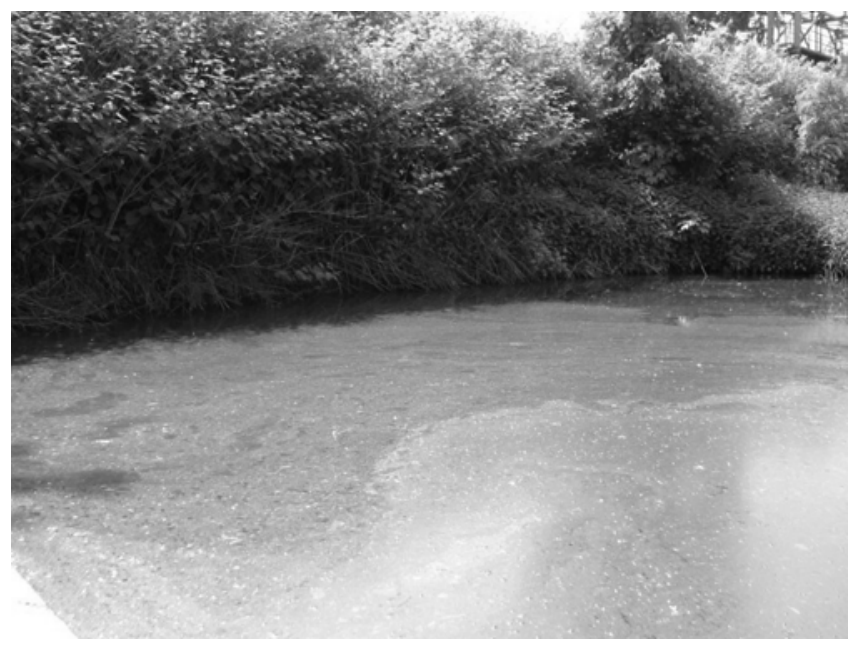

Figure 5. The sampling point of Sample 3

\section{SAMPLE 3}

The next sample was taken from the centre of the Cerny prikop's bed, which is between the sampling points 1 and 2 (Figure 5). The flotation experiment results are given in Table 5. The results imply that flotation is able to remove $96 \%$ of NEL, $72 \%$ of PCB and $77 \%$ of PAH from the sediments.

\section{SAMPLE 4}

The last sample was taken 50 meters from the levee and 2 meters from the bank (Figure 6). Table 6 states the results of its flotation experiments. It is clear from the obtained results that by applying flotation it is possible to remove $77 \%$ of NEL, $71 \%$ of $\mathrm{PCB}$ and $72 \%$ of $\mathrm{PAH}$ from the sediments.

It is apparent from the flotation experiments (See Tables 3 to 6) that the application of flotation on the given samples is highly effective and the acquired results are excellent. In the case of all the samples applying flotation it was possible to reach a pollutant recovery into the concentrate higher than $70 \%$, which means that given inexpensive technology it could be possible to treat such sediments which are still a great environmental strain for the City of Ostrava. 
Table 5. Flotation results - Sample 3

\begin{tabular}{|c|c|c|c|c|c|c|c|}
\hline \multirow{3}{*}{ Product } & \multirow{2}{*}{ Recovery } & \multicolumn{3}{|c|}{ Content } & \multicolumn{3}{|c|}{ Recovery } \\
\hline & & $\mathrm{PAH}$ & $\Sigma$ PCB & NEL & $\mathrm{PAH}$ & $\Sigma$ PCB & NEL \\
\hline & $\%$ & \multicolumn{3}{|c|}{$\mathrm{mg} / \mathrm{kg}$} & \multicolumn{3}{|c|}{$\%$} \\
\hline $\mathrm{K}$ & 63.47 & 548.67 & 352.44 & 4636 & 77.31 & 72.23 & 95.99 \\
\hline O & 36.53 & 279.76 & 235.32 & 1812 & 22.69 & 27.77 & 4.01 \\
\hline$P$ & 100 & 450.44 & 309.66 & 3065.4 & 100 & 100 & 100 \\
\hline
\end{tabular}

$\mathrm{K}$ - concentrate, $\mathrm{O}$ - tailings, $\mathrm{P}-$ feed

Table 6. Flotation results - Sample 4

\begin{tabular}{|c|c|c|c|c|c|c|c|}
\hline \multirow{3}{*}{ Product } & \multirow{2}{*}{ Recovery } & \multicolumn{3}{|c|}{ Content } & \multicolumn{3}{|c|}{ Recovery } \\
\hline & & $\mathrm{PAH}$ & $\Sigma \mathrm{PCB}$ & NEL & $\mathrm{PAH}$ & $\Sigma$ PCB & NEL \\
\hline & $\%$ & \multicolumn{3}{|c|}{$\mathrm{mg} / \mathrm{kg}$} & \multicolumn{3}{|c|}{$\%$} \\
\hline $\mathrm{K}$ & 51.48 & 558.38 & 565.77 & 5310 & 72.56 & 71.05 & 76.87 \\
\hline 0 & 48.52 & 224.06 & 244.55 & 1695 & 27.44 & 28.95 & 23.13 \\
\hline$P$ & 100 & 396.17 & 409.91 & 3556 & 100 & 100 & 100 \\
\hline
\end{tabular}

$\mathrm{K}$ - concentrate, $\mathrm{O}$ - tailings, $\mathrm{P}$ - feed

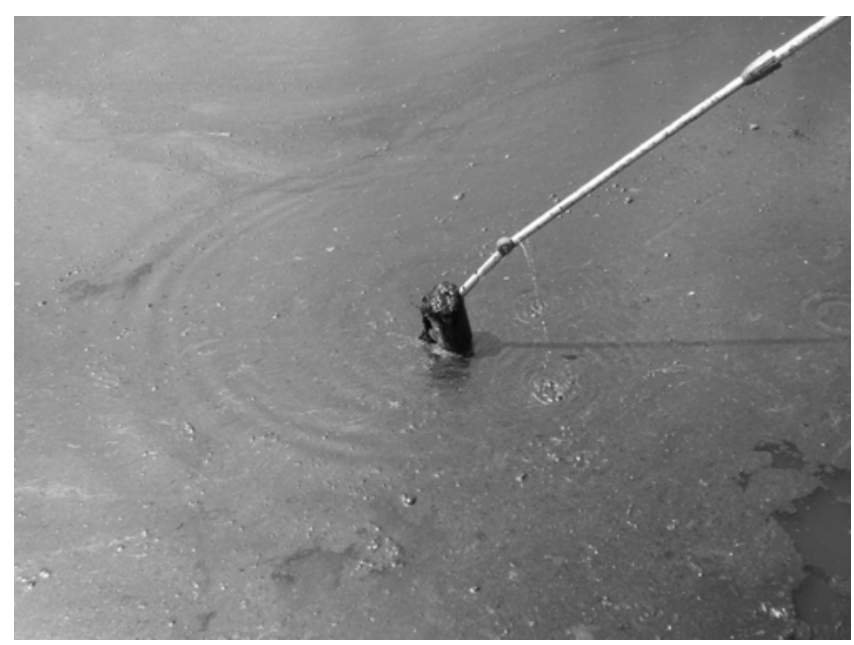

Figure 6. The sampling point of Sample 4

\section{CONCLUSION}

The objective was to verify the application of separation by flotation in the decontamination of sediment samples from the Cerny prikop situated in the City of Ostrava. The obtained results imply that the application of flotation is very effective and it is possible to apply it to eliminate harmful organic pollutants from the sediments in question.

\section{LITERATURE CITED}

1. Kmet, S. (1986). Flotation. Bratislava: Alfa. /in Slovak/.

2. Spaldon, F. (1983). Mineral Processing. Bratislava: Alfa. /in Slovak/.

3. Ahrens, M.J. \& Depree, C.V. Inhomogeneous distribution of polycyclic aromatic hydrocarbons in different size and density fractions of contaminated sediment from Auckland Harbour, New Zealand: an opportunity for mitigation.

4. Marine Pollution Bulletin, Volume 48, Issues 3 - 4, February 2004, Pages 341 - 350. Mulleneers, H. et al.: Remediation of fine fractions of dredged sediments by flotation. Environmental technology ISSN 0959-3330 2002, vol. 23, no 8, pp. 877 - 887 . 